\title{
The impact of geographic diversification on export performance of small and medium-sized enterprises (SMEs)
}

\author{
Jerzy Cieślik • Eugene Kaciak • Dianne H. B. Welsh
}

Published online: 12 February 2012

(C) The Author(s) 2012. This article is published with open access at Springerlink.com

\begin{abstract}
Two alternative diversification strategies - the geographic diversification of export sales and key market concentration-are extensively discussed in management, strategy, entrepreneurship, and economics literature. However, no conclusive evidence currently exists as to how either of these strategies affects the performance of international sales. This paper contributes to a better understanding of geographic diversification as a key dimension of the internationalization process for small and medium-sized enterprises (SMEs). In it, we analyze a comprehensive database of Polish exporters over a 3-year period to better understand the geographic diversification patterns of exporters. Based on this analysis, six propositions emerged from the export patterns examined and two viable strategies for exporting SMEs are identified: (1) concentrating on a single market and (2) a balanced approach aimed at targeting a small number of key markets, combined with a strategy of penetrating other markets. Implications for practice and future research are also discussed herein.
\end{abstract}

Keywords Exports - Geographic diversification · Market concentration · High-growth firms

\footnotetext{
J. Cieślik (凶)

Center for Entrepreneurship, Kozminski University, Jagiellonska 59, Warsaw, Poland e-mail: jerzy@cieslik.edu.pl

E. Kaciak

Department of Finance, Operations \& Information Systems, Brock University, St. Catharines, ON L2S 3A1, Canada

e-mail: ekaciak@brocku.ca

D. H. B. Welsh

Bryan School of Business and Economics, University of North Carolina at Greensboro, P.O. Box 26170, Greensboro, NC 27402-6170, USA

e-mail:dhwelsh@uncg.edu
} 


\section{Introduction}

The scope of geographic diversification of the international operations of firms is discussed in management, strategy, entrepreneurship, and economics literature as a key dimension of the internationalization process. It has been argued that by increasing the number of export markets (i.e., adding to the breadth of internationalization), a company's internationalization effort becomes more intense and deepens, a process that is typically measured by foreign sales/total sales ratio (FSTS, Thomas and Eden 2004; Pangarkar 2008). Other dimensions of internationalization intensity include level of international production (Thomas and Eden 2004; Jones and Coviello 2005) and product diversification (Chang 2007).

Previously, the research community has focused on the diversification of international activities of large multinational enterprises (MNE; Hitt et al. 1994, 1997); however, FDI operations, being the center of the MNE research, are beyond the scope of our analysis. In this paper, we focus on the diversification of international activities of small and medium-sized companies (SMEs). These SMEs are characterized by:

- Constraints in international operations due to limited financial, marketing and managerial resources (i.e., a weak infrastructure for conducting international operations); and,

- A predominant use of exporting (the simplest form of outward internationalization).

Once a smaller firm engages in exporting, it can either focus on key markets or widely diversify its export sales (Crick et al. 2000; Katsikea et al. 2005), yet no conclusive evidence has been offered concerning how these export expansion strategies affect the growth of international sales. Moreover, little evidence exists concerning existing trends in geographic diversification. This incomplete knowledge base impedes the advancement of research that could lead to meaningful recommendations for managers and policy makers. Therefore, the purpose of our study is to remedy this shortcoming by exploring patterns of geographic diversification of export sales.

More specifically, the aims of this study are twofold:

1. Identify the prevalence of the use by Polish domestic SMEs of two basic export expansion strategies identified in the literature, namely concentration and spreading, and

2. Identify alternative ambidexterity strategies that attempt to pursue both concentration and spreading.

Our paper is organized as follows. First, we review the literature on geographic diversification and its role in the internationalization process of SMEs, then we describe our procedure for selecting a sample of Polish exporters and the methodology used (cluster analysis). We discuss the results and put forth six propositions for future research that include conclusions, limitations, and recommendations for future research.

\section{Literature review}

With respect to the geographic diversification of export sales, the literature on the internationalization of SMEs involves two research directions. The first direction 
focuses on the relationship between international diversification and performance (i.e., viewing the concentration versus spreading either as a trade-off or as an effective combination of the two - the latter is known as an ambidexterity strategy). The second direction investigates the impact of diversification within the broader framework, taking into consideration not only the number of markets served but also the regional dimension of the diversification process. This approach looks at the extent an exporting company expands outside its home region and how many geographic regions it serves.

\section{Diversification versus concentration of export sales}

The apparent trade-off between a wider geographic diversification and a concentration on key destination markets has been the subject of substantial debate, particularly in export management literature. This trade-off is called the concentration versus spreading debate (Crick et al. 2000; Katsikea et al. 2005), and research into it began in the late 1970s and early 1980s (e.g., Piercy 1981). It gained importance in the $1990 \mathrm{~s}$ in relation to export performance whereupon the main conclusion was that performance results from export strategy, which includes the selection of foreign markets (Leonidou et al. 2010). Although the findings are inconclusive, they stress the rationale behind pursuing one approach versus another and relay that various situational factors play an important role in choice (Piercy 1982). Leonidou et al. (2002) based their meta-analysis on 36 studies specifically addressing market strategy, and found that the concentration strategy, which is dependent on the performance measure used, is positively related to export performance. In addition, a significant positive influence was found while using sales-based indicators. Weak associations were observed for the remaining measures, particularly the export market share. Similarly, market-spreading strategies were shown to be positively related to export performance, with the exception of export sales volume. The association was particularly strong when the share of exports in total sales was used as a performance indicator.

Katsikea et al. (2005) found long-term advantages of this spreading strategy when used to improve the effectiveness of sales management and personal selling activities. Spreading accelerates the process of accumulating diversified knowledge and experience, thus improving the competencies of the staff involved in international operations. Pangarkar (2008) incorporated the dispersion of foreign sales across a number of regions by measuring the degree of internationalization (DOI) and found that higher DOI (combining both export intensity and geographic dispersion) led to better performance of SMEs.

Lu and Beamish (2006) investigated the impact of internationalization on a firm's growth and financial performance and pointed out that the learning-from-exporting effect is a factor that facilitates building the strong capabilities that enable the implementation of comprehensive strategies (thereby contributing to an accelerated growth). Lages et al. (2006) stated that the learning process accelerates with the number and diversity of foreign markets served, particularly when previous experiences in some of the export markets have been positive. An additional advantage occurs because a broadly diversified market scope stabilizes a company's earnings due to uncorrelated economic cycles in the different countries to which they export. 
Widespread geographic diversification, however, is not without risks - particularly for SMEs. Pangarkar (2008) argued that SMEs are not smaller versions of larger companies, but are confronted with constraints in the internationalization process relevant to the pace of geographic diversification. For example, SMEs do not regularly scan the environment for information on a global scale and therefore frequently overlook opportunities in international markets. SMEs also lack managerial resources that need to be assigned to the opening of new markets. Once a smaller firm establishes a presence in overseas markets, a limitation to further expansion stems from a scarcity of managerial capacity and the lack of material infrastructure necessary for effective communication and coordination of a global network. At this stage, a proactive and well-planned geographic expansion strategy is recommended for SMEs (Eusebio et al. 2007).

Because SMEs often initiate exports early on without prior planning (e.g., by responding to unsolicited orders, Bilkey and Tesar 1977), these orders have been identified in a number of empirical studies as having a high impact on management's decision to expand internationally (Leonidou et al. 2007). The proactive adaptation and creative replication of operating patterns from early markets to new ones also depends on the fungibility (Autio 2005) and scalability of the resources, which generally reflects the firm's preparedness to internationalize (Zhou and de Wit 2009).

In the spreading versus concentrating strategy choice, the negative correlation between the number of markets served and the percentage of markets that are significant seems evident: the larger the proportion of goods that are channeled to a smaller number of key export markets, the less remains for sale to other markets. In reality, exporters may pursue both strategies simultaneously in that exports can be highly concentrated (e.g., $80 \%$ of exports go to one destination...) and simultaneously serve a large number of markets (...the remaining $20 \%$ are thinly spread among a large number of distant markets).

After compiling the results of studies on international marketing strategies, Aspelund et al. (2007) determined that the apparent success of some new international ventures are derived from the firm's effective implementation of both concentration and geographic strategy. Crick and Jones (2000) came to a similar conclusion. They found that such ventures tend to employ a market-spreading strategy because they actively search (globally) for opportunities, while simultaneously keeping much of the firm's resources committed to priority markets. Morgan-Thomas and Jones (2009) also demonstrated that firms which internationalize rapidly enter a larger number of foreign markets while at the same time relying heavily on key export destinationsmore so than firms that follow less aggressive internationalization strategies. A more refined formulation of the simultaneous use of concentration and spreading strategies is to adopt the concept of ambidexterity originally applied to international operations of large multinational enterprises. Ambidexterity addresses the need to simultaneously pursue exploratory strategies in new markets while continuing to exploit opportunities in established markets (March 1991; Barkema and Drogendijk 2007; Cellard and Prange 2008). In summary, despite a generally positive reputation of the diversification strategy for SMEs that was influenced largely by a similar debate for large MNEs (Contractor 2007), this type of strategy involves significant untenable risks, particularly for smaller firms with financial and human resource constraints and limited operational experience (Brouthers et al. 2009). 
Exporting to nearby versus distant markets and regions

In the incremental process model, exporters gradually gain experience while adding new export markets as they move from close proximity markets to ones that are more distant. In this model, the use of a large number of export markets, of which a significant number are distant, reflects a high degree of exporting maturity when the firm is engaged in an internationalization process (Johanson and Vahlne 1977). Thus, the number of markets and the size of the firm correlate positively with the (experiential) age of the firm (McNaughton 2003). In turn, Vachani (1991) pointed out that not only the number of export markets matters but also whether the company expands its international operations within a relatively homogeneous cluster of countries (related geographic diversification) or across heterogeneous geographic regions (unrelated geographic diversification).

The importance of geographic diversification has received considerable attention in the extant literature over last two decades and is identified as a crucial characteristic of born global (BG) firms. Oviatt and McDougall (1994) define (p. 49) an international new venture (INV) as "a business organization that from inception seeks to derive significant competitive advantage from the use of resources and the sale of outputs in multiple countries." Later on, the scope of geographic diversification was viewed as a key differentiating factor between INVs and those labeled as "born global" or "truly born global firms." Luostarinen and Gabrielsson (2004) illustrated that a born global firm must have business activities in at least two geographic regions. Similarly, Kuivalainen et al. (2007) distinguished truly born global firms as those that operate in multiple and distant markets.

Following the methodology adopted in the debate on global versus regional characteristics of top MNEs (Rugman and Verbeke 2004), Crick (2009) puts forward a formalized categorization of BGs and INVs (the latter of which only needs to internationalize within three years from its formation, with export sales directed to at least three overseas markets that represent at least $30 \%$ of total sales). To qualify as a $\mathrm{BG}$, the firm must derive at least $10 \%$ of its turnover from each of three broadly defined triad markets: North America, Western Europe, and Southeast Asia.

\section{Geographic diversification and export performance}

Early internationalizing firms do not possess established operating routines geared toward domestic markets and are quicker to absorb knowledge about dealing in foreign markets and subsequently change their processes to accommodate the needs of these markets more efficiently (Autio et al. 2000). This, in turn, facilitates a rapid expansion of international activities. As a result, early internationalization (precocity), combined with the rapidity of the internationalization process (Zucchella et al. 2007), has a positive impact on the level of geographic diversification (McNaughton 2003).

Larimo's (2006) study of Finnish SMEs challenges the link between the extraordinary performance and the strategy of rapid international diversification. Although the evidence generally confirms a relationship between the two, the findings primarily apply to traditional exporters and less to firms with intensive export operations (labeled by the author as truly born internationals). SMEs included in the latter 
category concentrate their export operations on key destinations and performed better by achieving a higher FSTS ratio.

The literature reports different results from the combined effects of differences in language, culture, consumer behavior, and the legal framework of early internationalizing firms. These differences are termed psychic distance or country distance, and they impede the flow of information and cause uncertainty in foreign markets (Jones and Coviello 2005). In view of the financial, marketing, knowledge, and managerial constraints faced by young and small firms, what matters is not just the number of markets served, but also the effect of expanding operations beyond the home region into one or more host regions. Taking into account recent progress in regional integration [e.g., the European Union (EU) or NAFTA], the removal of barriers in the flow of goods, services, and capital has a positive impact on the regional operations of smaller firms. This is because the differences between conducting domestic and regional export sales in terms of operations often become negligible-especially when sales within the EU single market are no longer considered "exports" but "intracommunity" trade.

On the other hand, some authors emphasize benefits of operating outside of the home region. A number of factors underlie a direct, positive relationship between extended international diversification and performance (Zahra et al. 2000). Entering new markets enables a company to exploit market opportunities and gain access to an extended business network. The learning-from-exporting argument advanced by Salomon and Shaver (2005) is particularly relevant here-exporters receive valuable marketing and technological knowledge while operating in a diversified international environment. Similarly, Preece et al. (1999) articulate a difference between going international and going global.

In contrast to the above, Beleska-Spasova and Glaister (2010) hypothesized that smaller exporters, unlike large MNEs, are less able to absorb the costs associated with international expansion. As a result, those exporters concentrating on the home region often perform better than those trading predominantly in the other triad regions, although this hypothesis is not supported by empirical research. Similarly, mixed results were drawn from a large panel study on German nonexporters (those exporting to the eurozone and those exporting outside the eurozone, Verardi and Wagner 2010). After eliminating sample outliers, the differences in the productivity premia between these categories of firms proved to be insignificant.

While regional integration facilitated the international operations of smaller firms within regional country groupings, other developments paved the way for their global expansion thereby resulting in substantial progress in lowering or dismantling international trade barriers. The key driver was the information and communication technology (ICT) revolution that resulted in better communication and decreased cost of international operations (Ruzzier et al. 2006). Modern ICT enabled the implementation of new business models and facilitated participation of smaller firms in global production and service networks (i.e., by means of subcontracting, offshoring). With the use of ICT, global niche markets opened up to SMEs and small batch production became economically viable. Finally, the integration of the former communist countries in the market system and the emergence of new players like China, India, or Brazil created new, more diversified environments for conducting business internationally. 


\section{Methods and measures}

Based on an existing review of the literature, we conclude that the influences of serving differentially located markets and the respective benefits of spreading versus concentration strategies are underresearched, particularly with regard to the internationalization of SMEs. In addition, we believe that the data on the general patterns of geographic diversification of SME exports are largely lacking. There is no standardized data collection, no measures in governmental census data systems, and an absence of empirical research in various countries. These factors seriously constrain any research that pursues the deductive approach of testing hypotheses derived from existing literature, and have pointed the authors towards: (1) employing the inductive approach (Locke 2007) and (2) applying a cluster analysis (enhanced by ANOVA and $t$ tests) to discover meaningful relationships among the cases. Cluster analysis is used in theory-building research in a number of studies, including Hill and Brennan (2000) and Raymond and Croteau (2006), and clusters can emerge from analysis inductively even though the categories are set by the researchers a priori deductively (Dadzie 1998; Spens and Kovács 2006). Analysis of a large dataset using the cluster method helped us identify general trends and patterns in export diversification and allowed us to create a set of propositions that can be addressed in future research.

\section{Data collection}

An analysis of export sales on a large database of Polish export sales engaged in the commodity trade was conducted during the years 2003-2006. Input data were obtained from the Foreign Trade Data Centre (FTDC) and the Analytical Centre of Customs Administration (ACCA). Prior to 2003, all exporters were obliged to submit data. This requirement was waived for exporters that exported less than 230,000 USD annually after Poland's accession to the EU in 2004.

Out of approximately 50,000 exporting firms, we selected 12,409 exporters that exceeded a minimum threshold of 230,000 USD in sales volume during 2003. These 12,409 exporters became what we refer to as the FTDC-ACCA database. The reason for setting up a minimum export volume is twofold.

First, this was required for measuring export growth in a manner consistent with the recently adopted OECD methodology, which requires meeting a minimum threshold in the base year (OECD 2008). As an equivalent of ten employees, we used export volume (230,000 USD) from the Polish customs system to categorize the so-called microexporters.

Second, a recent study (Cieślik et al. 2010) demonstrated the existence of a sizeable and distinct group of exporters that do not survive as exporters after initial attempts or that engage sporadically in international sales with export volumes remaining at very low levels.

To investigate the impact of geographic diversification on the growth of export sales, we focused on the largest group of exporters operating in the manufacturing sector (the second largest category of exporters is comprised of trading companies that operate only as intermediaries in the export process). Service firms were 
excluded because customs procedures only apply to the commodity trade. All subsidiaries of multinational companies were also excluded because the operational and geographic diversification of export sales these firms display is dependent on links with parent and other affiliated companies within the international production and sales networks.

Finally, because our study focuses on small and medium-sized exporting firms, large outlying domestic firms were eliminated. Based on a comparative analysis using other statistical data sources, the researchers chose the export sales volume of 5.7 million USD in 2006 as the threshold for excluding large exporting firms from this study of versus small and medium-sized ones. A similar approach was used by Morgan-Thomas and Jones (2009) who eliminated firms employing more than 250 full-time employees from their sample in order to fit the standard EU definition of SMEs. Verardi and Wagner (2010) conducted a similar study on German exporters and pointed to the potentially negative consequences of extreme observations, or outliers. Since a large share of exports is performed by a few big firms that export to a large number of countries (which is also true for Poland), the inclusion of such firms in the analysis may distort the results. This multistage selection process provided the researchers with 3,609 Polish domestic exporting SMEs - suitable for a cluster analysis to identify general patterns in the geographic diversification of export sales.

\section{Measures}

\section{Diversification measures}

The analysis of the determinants of export performance represents one of the most widely debated subjects in the internationalization research. Based on five review articles summarizing the results of research during 1975-2005, the geographic diversification issue received relatively limited attention. In their export strategic model, Aaby and Slater (1989) placed geographic diversification within market selection variables, which, in addition to diversification, include the strategic focus on certain markets or regions. Zou and Stan (1998) do not specify geographic diversification in their export performance model; however, it was included in a broader category of the general export strategy of the firm. Katsikea et al. (2000) do not specifically mention geographic diversification, but include it among their targeting factors (these factors cover aspects such as export expansion strategy, and foreign market segmentation). Targeting factors in their export performance model represent intervening variables that directly affect performance.

The two most recent literature reviews cover research up to 2005. Wheeler et al. (2008), in their review of UK research, clearly identify geographic diversification (measured by the number of export markets) as an independent variable (this issue was investigated in four out of 33 studies surveyed). Sousa et al. (2008) did not specify geographic diversification as a separate variable but included it within a broader category of export marketing strategy (it was addressed in only three out of 52 studies conducted from 1998 to 2005).

The number of export markets is the metric most often used to measure geographic diversification. As discussed previously, there is also a growing interest in incorporating the regional dispersion of international sales of SMEs into the analysis, taking 
into account the psychic distance between home and host regions. For example, Beleska-Spasova and Glaister (2010) followed the methodology put forward by Rugman and Verbeke (2004) for categorizing the largest MNEs to create a similar classification for UK exporting SMEs. These categories include home region, biregional, host regional, and global orientations. Meanwhile, Pangarkar (2008) used an alternative approach by modifying the traditional FSTS ratio. Namely, he introduced composite measures to add weight to the dispersion of international sales (outside the home region) and psychic distance differences.

In our research, we capture the various dimensions of geographic diversification as well as the potential interactions among them (used in previous research), which include:

- The number of export markets (this standardized measure was used as reflected in the literature)

- Concentration on the home region versus the host region: To reflect the psychic, or country distance, Polish exporters are divided into two groups: those with over $50 \%$ of their exports to the "home" EU single market and those concentrating predominantly on markets outside the EU. Such categorization reflects recent findings pointing to the positive impact of home region concentration on export performance (Lee 2010). The EU market is the most important export destination for Polish firms, comprising over $80 \%$ of total exports in 2006 . This market has grown since Poland's induction into the EU in May of 2004. For Polish exporters, the country's accession into the EU in 2004 resulted in an increasing gulf-in operations and perceptions - between the largely homogenous EU single market and the rest of the world. We do not attempt to categorize the key Polish export markets outside the EU into regions because they are widely dispersed and do not form homogeneous groups. The triad regional classification was not useful for categorizing Polish exporting SMEs due to their marginal presence in both Asian and North American regions.

- Concentration of export sales on one key market is measured by the percentage of export sales channeled to the largest host country-either within the EU or outside the EU. A smaller exporter facing financial and human resource constraints may opt for having the majority of its export sales channeled to just one market. Obviously, such a strategy is not without risks, specifically once the economic conditions in the lead market deteriorate. This measure seems suitable for capturing the impact of the "natural" lead country destinations either due to the size of their economies, longstanding relationships (such as between Canada and the USA; Francis and Collins-Dodd 2004), or historic links such as those that are tied to a colonial past (Shepherd 2010). Some authors argue that in firms that expand rapidly, the geographic scope of operations and psychic distance become less important, giving way to selecting export markets where the most promising opportunities are identified. In particular, firms operating in the high-tech, knowledge-based industries since their inception focus on the "lead markets," the home market being just one of these. Consequently, it may occur that exports precede domestic sales during the initial stages (Bell et al. 2003; Morgan-Thomas and Jones 2009; Kudina et al. 2008). In turn, Brouthers et al. (2009) found that export sales predominantly directed towards a single market is an extreme form of concentration that leads to higher export performance. 


\section{Measuring export performance}

We did not have access to economic and financial company data other than export sales and their composition. As a result, it was not possible to use standard financial performance measures. However, since we had access to a series of data at the firm level from 2003 through 2006, we were able to calculate the growth of export sales for this period (used in our study as the single measure of export performance). Irrespective of the constraints as to the choice of alternative measures, the export growth ratio seems to be particularly useful for measuring the effects of geographic diversification because both independent and dependent variables are related exclusively to export sales. Nevertheless, the FSTS ratio is less useful here as the respective changes of this ratio could depend on the relative trends in the growth of export and domestic sales.

Based on a comprehensive review by Katsikea et al. (2000), export sales growth was used as an export performance indicator in 41 out of the 93 studies and ranked second in the frequency of appearance (after the most widely used FSTS ratio). Recent studies using this measure include Francis and Collins-Dodd (2004), Kuivalainen et al. (2007), and Matanda and Freeman (2009).

In order to calculate export growth rates, this paper integrates recent definitions and conventions advanced by the OECD (2008) to identify high-growth firms. The proposed OECD format stipulates that annualized growth rates be measured over a minimum of 3 years. High-growth firms are those that achieve at least a $20 \%$ annualized growth in sales and/or employment. To eliminate cases where high growth is exclusively the result of low base values and to allow for more meaningful comparative analyses, OECD methodology introduced a minimum threshold level of ten employees in the base year. Consequently, the firms below such a threshold in the base year were eliminated from the growth analysis. Because employment data were unavailable, the minimum threshold for the small exporter category used in the customs data processing (230,000 USD) was adopted as a surrogate. Accordingly, all of the 3,609 exporting SMEs included in the sample surpassed the minimum threshold of 230,000 USD in export sales in 2003.

\section{Analysis}

Initial categorization of exporters

To capture the diversity in the population of exporters, the firms were divided into six groups based on two criteria:

1. An export growth ratio between 2003 and 2006 and

2. A psychic, or country distance, as reflected in the concentration of export activity at the home region (EU) versus host markets outside the home region.

The initial categorization procedure of the population of 3,609 manufacturing exporters produced six groups of firms:

(a) High-growth exporters with at least $50 \%$ of exports directed to the EU market (711 firms), 
(b) Slow-growing exporters with at least $50 \%$ of exports directed to the EU market (806 firms),

(c) High-growth exporters with over $50 \%$ of exports directed outside the EU (225 firms),

(d) Slow-growing exporters with over $50 \%$ of exports directed outside the EU (175 firms),

(e) Declining exporters with at least $50 \%$ of exports directed to the EU market (1,183 firms), and

(f) Declining exporters with over $50 \%$ of exports directed outside the EU (509 firms).

\section{Clustering variables}

The firms in each subgroup are organized around two measures of geographic diversification: (1) the number of export markets and (2) the percentage of exports going to the key country market. To reveal natural groupings (clusters) within each of the six data sets, we used the two-step cluster analysis, which groups cases into preclusters that are treated as a single case (Zhang et al. 1997). In the second step, we applied standard hierarchical clustering to the preclusters.

Two-step clustering is a one-pass-through-the-dataset method and is recommended for large datasets because it does not require a proximity table (e.g., hierarchical classification) or an iterative process (e.g., K-means clustering). Research that uses this algorithm assumes that continuous variables are independent and follow a normal distribution while the categorical variables are independent and follow a multinomial distribution. The algorithm is fairly robust, however, to violations of independence and distributional assumptions (Chiu et al. 2001). That being said, it also automatically determines the number of clusters on the basis of either the Schwarz Bayesian Criterion (BIC) or the Akaike information criterion (AIC). Our analysis used the BIC since it is more appropriate than the AIC when the goal is exploration rather than prediction (Kuha 2004). The number of clusters can also be determined "manually" by examining the ratio of distance measures (Chiu et al. 2001). Based on the changes, both in the BIC and in the ratio of distance measures, we arrived at 24 clusters in total: five clusters in groups $\mathrm{A}$ and $\mathrm{B}$, three clusters in groups $\mathrm{C}$ and $\mathrm{D}$, five clusters for group $\mathrm{E}$, and three clusters for group $\mathrm{F}$, as illustrated in Fig. 1.

\section{Additional cluster characteristics}

Over and above the number of export (country) markets served and the percentage share of key market variables, additional characteristics are presented in Table 1, which examines the differences among the individual clusters and their groupings.

Export volume in 2006 The population of exporters studied consists only of small and medium-sized domestic exporters. Micro and large exporters are excluded as the level of export sales within this population is expected to vary across clusters. As sales volumes grow, we can assume firms become better equipped to diversify into a 
EU CONCENTRATED EXPORTERS

High-growth (Group A)

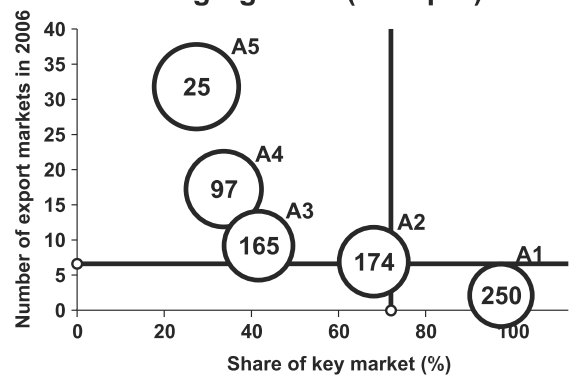

Slow growing (Group B)

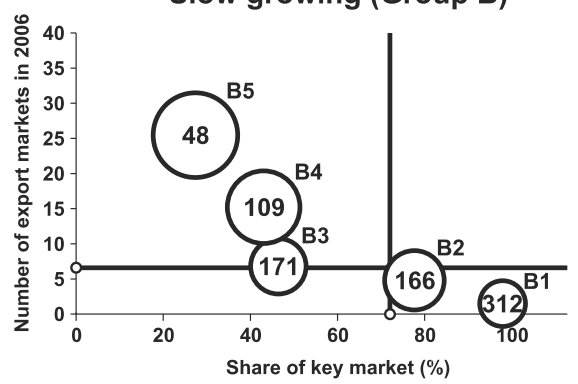

Declining (Group E)

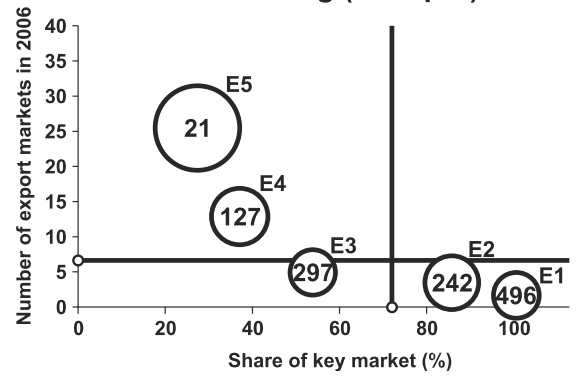

NON-EU CONCENTRATED EXPORTERS

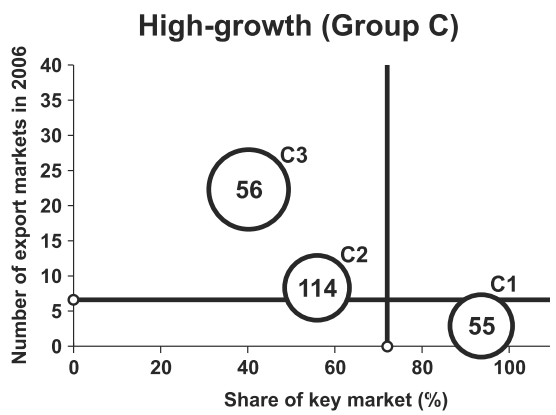

Slow growing (Group D)

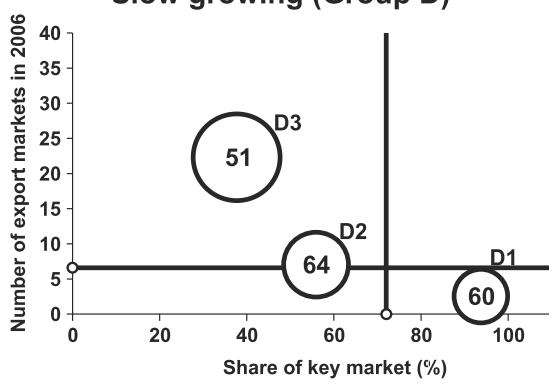

Declining (Group F)

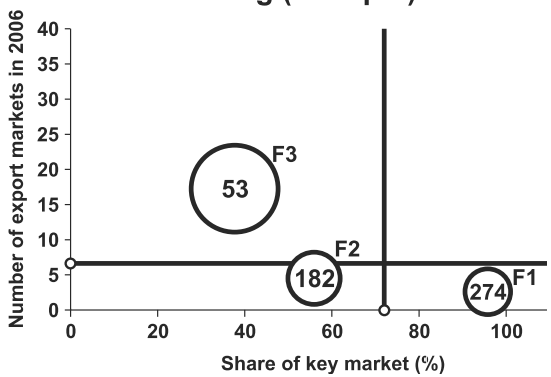

Fig. 1 Polish manufacturing sector 2003-2006; graphical depiction of clusters. Note 1: the mean value of export sales in 2006 for all firms in each cluster is depicted by the area of the corresponding circle. Note 2: the two horizontal and vertical axes represent the mean percentage of share of the key market and the mean value of the number of export markets, respectively, for the entire population of firms under study. Source: own display based on the FTDC-ACCA database

larger number of export markets. This argument has been well supported in the export management literature (e.g., Calof 1993; O’Cass and Weerawardena 2009; Brouthers et al. 2009).

Firm age and time to internationalization variables are common in the internationalization and born global literature (e.g., Acedo and Jones 2007; Zucchella et al. 2007; Morgan-Thomas and Jones 2009; Singh et al. 2010; Lin et al. 2011; Khavul et al. 2010) because these variables are expected to vary across derived clusters and are often used in studies on firm internalization using clustering techniques (Aspelund and Moen 2005). 


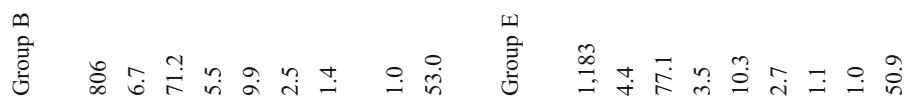

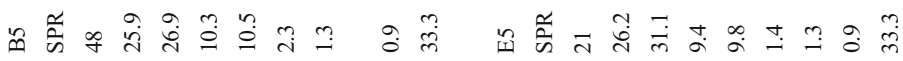

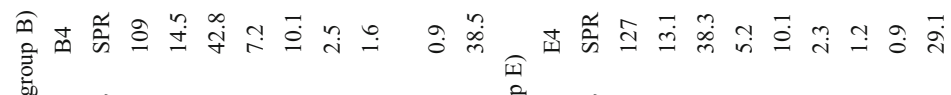

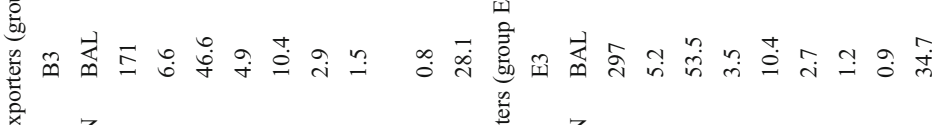
童

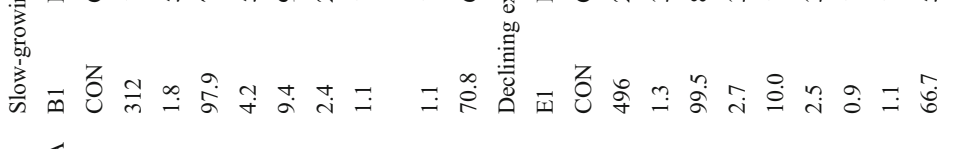

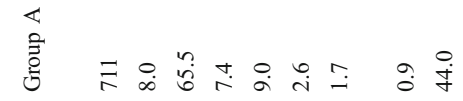

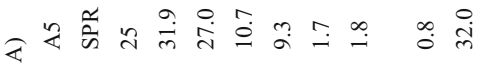

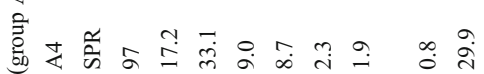

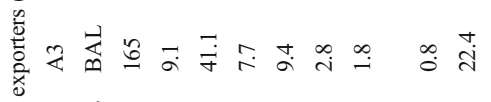

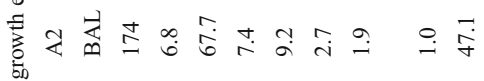

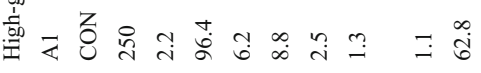




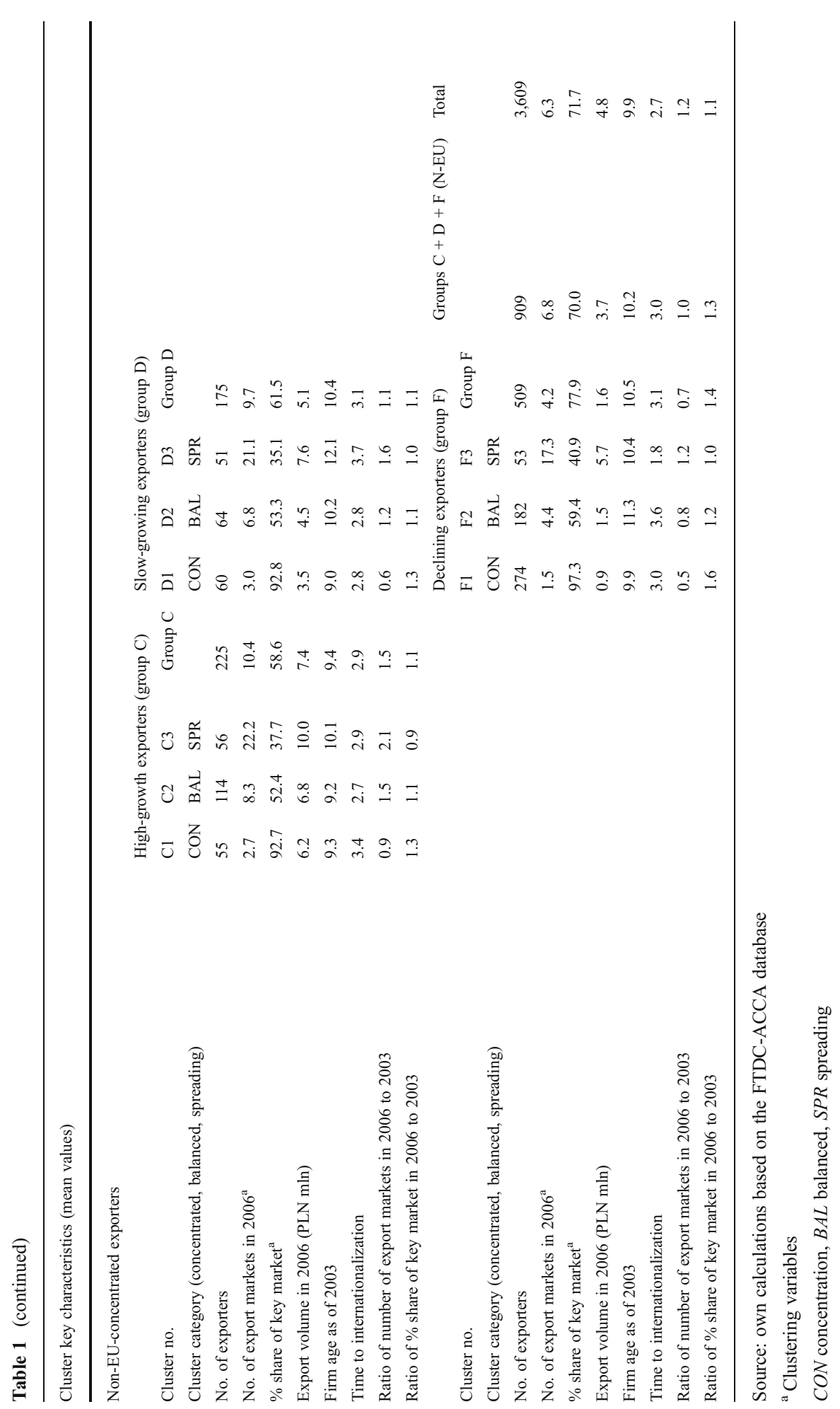


Two additional cluster characteristics are included:

1. The ratio of the number of export markets served in 2006 to 2003: A similar variable was used by Cabrol and Nlemvo (2009), who examined the evolution of geographical areas targeted by exporting companies between the first year of internationalization and the last year observed.

2. The ratio of the percentage share of the key market in 2006 to 2003: These measures are intended to capture the directions of change of the clustering variables over the time period proposed. In other words, we explore whether the differentiating growth trajectories of export sales are reflected in the overall trends of increases/decreases in the number of markets served and the increasing/ decreasing concentration of key markets.

Finally, this study examines the impact of the concentration of export sales on the German market. Due to the size of the economy, its geographic proximity, and its historic and cultural traditions, Germany has become Poland's primary trading partner for almost $50 \%$ of all Polish firms that primarily export to the EU (see Table 1). Thus, Germany as a key market characteristic measures the share of Germany-focused exporters among all exporting firms in a given sample. This corresponds to the measure used by Francis and Collins-Dodd in their 2004 study of the percentage of exports to Canada's nearest neighbor, the USA.

\section{Propositions}

Based on the two-step cluster analysis procedure and measurements by the annualized growth rate of export sales, similar patterns of diversification among exporters that concentrate on the EU and non-EU markets (irrespective of their export dynamics) were observed (Fig. 1).

To confirm this visual observation, the percentage share of the key market (one of the two clustering variables) for the five clusters in groups A, B, and E (all EUconcentrated exporters) were sorted within each group in ascending order (i.e., by increasing value). The correlation coefficients between the two sets of share percentages (group A versus group B, group A versus group E, and group B versus group E) were very high and ranged from 0.98 to 0.99 . Similarly, high correlation coefficients were also obtained for the second cluster variable (the number of export markets).

The same procedure was applied to the non-EU-concentrated exporters in clusters represented by groups C, D, and F. The correlation coefficients were high. Thus, regardless of the export dynamics (high, slow, or declining growth firms), the patterns of diversification among manufacturing firms that focused on either the EU or nonEU markets are similar. Based on these insights, the following proposition is advanced:

Proposition 1 Export diversification patterns within the EU and the non-EU markets are similar, regardless of the export dynamics (high, slow, or declining growth firms).

A one-way ANOVA test illustrated that the effect of export dynamics (high, slow, or declining growth) on average export volume in 
2006 was significant overall $(F(2,2697)=176.54, p<0.001)$. Subsequent post hoc tests (Tamhane's T2 test was used-since equal variances could not be assumed, according to Levene's test) demonstrate that the high-growth exporters to the EU markets in group A $(n=711)$ are statistically significantly larger $(p<0.001)$ in terms of their average export volume (2.1 million USD; Table 1$)$ than their slower growing counterparts in group $\mathrm{B}(n=806 ; 1.6$ million USD; Table 1). Furthermore, the slow-growing exporters to the EU markets in the above group B are statistically significantly larger $(p<0.001)$ in terms of their average export volume than firms with declining growth in group $\mathrm{E}(n=1,183,1.0$ million USD; see Table 1).

A similar result was achieved when average export volumes were compared among the exporters to non-EU markets. A one-way ANOVA showed that the effect of export dynamics (high, slow, or declining growth) on average export volume in 2006 was also significant overall $(F(2,906)=216.768, p<0.001)$. Subsequent post hoc tests using Tamhane's T2 test demonstrated that high-growth exporters to non-EU markets in group $\mathrm{C}(n=225)$ are statistically significantly larger $(p<0.001)$ in terms of their average export volume $(2.1$ million USD) than their slow-growing counterparts $(n=175)$ in group D (1.5 million USD) (see Table 1). The slow-growing exporters to non-EU markets in group D are statistically significantly larger $(p<$ 0.001 ) in terms of their average export volume than firms with declining growth in group $\mathrm{F}(n=509,0.5$ million USD; see Table 1$)$.

The findings indicate that within the range of sales adopted to define small and medium-sized exporters (between USD 0.2 million and 5.8 million), larger exporting firms enjoy the benefits of economies of scale, but are not yet confronted with the saturation of key markets or the adverse reaction of domestic and international competition. These exporters illustrate the positive relationship between the degree of internationalization and performance for companies "in the middle range of internationalization" found in the literature (Kuivalainen et al. 2007). Limited resources encourage firms to seek efficient organizational arrangements (e.g., partnerships and networks) that help accelerate international sales without escalating the administrative costs typically involved in setting up individual sales and distribution organization abroad.

Proposition 2 High-growth exporters that concentrated on either the EU or the nonEU markets have higher export volumes than their slow-growing counterparts, and those, in turn, have higher export volumes than the declining exporters.

As outlined in the second section of this paper that addresses the concentration versus spreading strategies, the average value of each of the two clustering variables for every one of the 3,609 firms was calculated. The average number of markets served is 6.3 , whereas the average share of the key market is $71.7 \%$ (see Table 1). Out of the total number of 24 clusters, 9 clusters were identified that fall into a 
spreading strategy - the cluster's average number of markets served was much greater than 6.3 and its average percentage share of the key market was much less than $71.7 \%$, and there are eight clusters that fall clearly into the concentration strategy.

The cluster analysis also revealed that, within the EU, exporters that followed the concentration strategy were largely dependent on the German market (63.6\% of exported volume), while among those following the spreading strategy, such dependence was much weaker (32.5\% of exported volume, see Table 2$)$. A two independent samples $t$ test further demonstrates that the choice between concentration and spreading strategies is strongly affected by the size of the export operations $(t=-19.8 ; p<0.001)$. Larger exporters tend to serve a higher number of markets and place a lower percentage of their exports in key markets. The average export sales for the group of

Table 2 Polish manufacturing exporters 2003-2006 by diversification strategies and export orientation (mean values)

\begin{tabular}{|c|c|c|c|c|c|c|c|c|c|c|}
\hline \multirow{2}{*}{$\begin{array}{l}\text { Diversification strategy } \\
\text { Export orientation }\end{array}$} & \multicolumn{3}{|c|}{ Concentration } & \multicolumn{3}{|c|}{ Balanced } & \multicolumn{3}{|c|}{ Spreading } & \multirow[t]{2}{*}{ Total } \\
\hline & $\mathrm{EU}$ & Non-EU & Total & $\mathrm{EU}$ & Non-EU & Total & $\mathrm{EU}$ & Non-EU & Total & \\
\hline No. of exporters & 1466 & 389 & 1855 & 807 & 360 & 1167 & 427 & 160 & 587 & 3609 \\
\hline $\begin{array}{l}\% \text { of the total number } \\
\text { of exporters }\end{array}$ & 40.6 & 10.8 & 51.4 & 22.4 & 10.0 & 32.3 & 11.8 & 4.4 & 16.3 & 100.0 \\
\hline $\begin{array}{l}\% \text { of the total number } \\
\text { of exporters within } \\
\text { EU }\end{array}$ & 54.3 & & & 29.9 & & & 15.8 & & & 100.0 \\
\hline $\begin{array}{l}\% \text { of the total number } \\
\text { of exporters within } \\
\text { non-EU }\end{array}$ & & 42.8 & & & 39.6 & & & 17.6 & & 100.0 \\
\hline $\begin{array}{l}\text { No. of export markets } \\
2006^{\mathrm{a}}\end{array}$ & 2.4 & 1.9 & 2.3 & 6.6 & 6.1 & 6.5 & 17.6 & 20.2 & 18.3 & 6.3 \\
\hline $\begin{array}{l}\% \text { share of key market } \\
2006^{\mathrm{a}}\end{array}$ & 93.7 & 96.0 & 94.1 & 52.6 & 56.1 & 53.7 & 36.0 & 37.9 & 36.5 & 71.7 \\
\hline $\begin{array}{l}\text { Export volume in } 2006 \\
\text { (PLN mln) }\end{array}$ & 4.1 & 2.1 & 3.7 & 5.5 & 3.7 & 4.9 & 7.7 & 7.8 & 7.7 & 4.8 \\
\hline Firm age as of 2003 & 9.8 & 9.7 & 9.8 & 9.9 & 10.4 & 10.1 & 9.8 & 10.8 & 10.1 & 9.9 \\
\hline $\begin{array}{l}\text { Time to } \\
\text { internationalization }\end{array}$ & 2.6 & 3.1 & 2.7 & 2.8 & 3.2 & 2.9 & 2.3 & 2.8 & 2.4 & 2.7 \\
\hline $\begin{array}{l}\text { Ratio of number } \\
\text { of export markets } \\
\text { in } 2006 \text { to } 2003\end{array}$ & 1.2 & 0.6 & 1.0 & 1.5 & 1.1 & 1.4 & 1.5 & 1.6 & 1.5 & 1.2 \\
\hline $\begin{array}{l}\text { Ratio of \% share of } \\
\text { key market in } 2006 \\
\text { to } 2003\end{array}$ & 1.1 & 1.5 & 1.2 & 0.9 & 1.2 & 1.0 & 0.9 & 1.0 & 0.9 & 1.1 \\
\hline $\begin{array}{l}\text { Germany as key market } \\
-\% \text { of cluster firms } \\
\text { (EU only) }\end{array}$ & 63.6 & & & 33.5 & & & 32.5 & & & 49.7 \\
\hline
\end{tabular}

Source: own calculations based on the FTDC-ACCA database

${ }^{\text {a }}$ Clustering variables 
firms that follow the spreading strategy was 2.2 million USD. Conversely, smaller exporters with average export sales of 1.1 million USD adhere to the concentration strategy and rely above all on the firm's key export market. These findings generally confirm previous results (McNaughton 2003; Calof 1993).

Proposition 3 Exporters that follow the spreading strategy have higher export volumes than those that follow the concentration strategy.

Following Brouthers et al. (2009), we conducted an additional analysis on the intensive forms of concentration reflected in directing export sales predominantly to a single market. The results presented in Table 3 demonstrate that almost half of the Polish SMEs direct over $50 \%$ of their export sales to a single market. This supports the conclusion by Brouthers et al. (2009) that a single market concentration can be a viable option for smaller exporters. We also found that $24.4 \%$ of Polish SMEs sell abroad to just one country-typically Germany. In the latter case, there are significant differences among the major categories of exporters. The single market concentration was followed by $13.2 \%$ high-growing, $19.2 \%$ slow-growing, and $33.6 \%$ declining exporters. These results point to the apparent risk of a single country market, particularly for companies pursuing an ambitious export development strategy, which leads to the following proposition:

Table 3 SMEs in the Polish manufacturing sector 2003-2006; concentration of export sales on a single market

\begin{tabular}{|c|c|c|c|c|c|c|}
\hline & \multicolumn{2}{|c|}{ Number of exporters } & \multirow[t]{2}{*}{ Total } & \multicolumn{2}{|c|}{$\%$ of the total } & \multirow[t]{2}{*}{ Total } \\
\hline & $\mathrm{EU}$ & Non-EU & & $\mathrm{EU}$ & Non-EU & \\
\hline \multicolumn{7}{|l|}{ High growing (HG) } \\
\hline Total & 711 & 225 & 936 & 100.0 & 100.0 & 100.0 \\
\hline Of which key market $>50 \%$ & 339 & 116 & 455 & 47.7 & 51.6 & 48.6 \\
\hline Of which key market $=100 \%$ & 108 & 16 & 124 & 15.2 & 7.1 & 13.2 \\
\hline \multicolumn{7}{|l|}{ Slow growing (SG) } \\
\hline Total & 806 & 175 & 981 & 100.0 & 100.0 & 100.0 \\
\hline Of which key market $>50 \%$ & 419 & 83 & 502 & 52.0 & 47.4 & 51.2 \\
\hline Of which key market $=100 \%$ & 167 & 21 & 188 & 20.7 & 12.0 & 19.2 \\
\hline \multicolumn{7}{|l|}{ Declining (DECL) } \\
\hline Total & 1,183 & 509 & 1,692 & 100.0 & 100.0 & 100.0 \\
\hline Of which key market $>50 \%$ & 559 & 240 & 799 & 47.3 & 47.2 & 47.2 \\
\hline Of which key market $=100 \%$ & 385 & 183 & 568 & 32.5 & 36.0 & 33.6 \\
\hline \multicolumn{7}{|l|}{$\mathrm{HG}+\mathrm{SG}+\mathrm{DECL}$} \\
\hline Total & 2,700 & 909 & 3,609 & 100.0 & 100.0 & 100.0 \\
\hline Of which key market $>50 \%$ & 1,317 & 439 & 1,756 & 48.8 & 48.3 & 48.7 \\
\hline Of which key market $=100 \%$ & 660 & 220 & 880 & 24.4 & 24.2 & 24.4 \\
\hline
\end{tabular}

Source: own calculations based on the FTDC-ACCA database 
Proposition 4 Concentrating a majority of export sales on a single market is a viable option for exporting SMEs but it may hamper the growth of export sales.

None of the 24 clusters fell within the ambidexterity quadrant where the number of markets served and the percentage of exports sent to the lead market are above the mean values for the entire population (note the upper-right quadrants in Fig. 1). Only 125 firms $(3.5 \%)$ were identified that met the ambidexterity criteria. These "ambidextrous" firms are scattered across 24 clusters: $27.2 \%$ are in cluster B2 and $20.0 \%$ are in cluster A2. This group of exporters is highly diversified and has a slightly higher (34.4\%) representation of high-growth exporters than does the entire population $(25.9 \%)$.

These findings contradict some of the literature, particularly those theses that have pointed to the ability of born global firms to follow an ambidexterity strategy successfully (Aspelund et al. 2007). The explanation for this apparent contradiction lies in the lack of international experience, their insufficient managerial capacity, and the deficiency of material infrastructure necessary for the effective communication and geographic coordination of diversified operations of the born global firms. Therefore, young internationalized firms cautiously expand by diversifying into a small number of export markets to utilize their scarce managerial, financial, and infrastructure resources efficiently.

Therefore,

Proposition 5 An extreme ambidexterity strategy of simultaneously pursuing a high concentration of export sales within a key market and with a large number of markets served is not a viable option for SMEs involved in exporting.

The cluster analysis identified a group of manufacturing exporters (clusters A2, A3, B3, E3, C2, D2, and F2) that follow neither the spreading nor the concentration strategy, but instead follow a balanced strategy (see Table 1). These exporters serve a nearly average (6.3 for the entire population) number of markets and are able to lower their dependence on the key export markets significantly because their average percent share of their key markets remains below that for the entire population.

A balanced strategy has not yet been identified in the extant literature. According to our findings, it has however been followed by almost a third $(32.3 \%)$ of Polish manufacturing exporters (See Table 2). This balanced strategy is almost as popular as the concentration strategy among exporters that deliver a majority of sales to the markets outside the EU (39.6\%, compared to $42.8 \%$ of exporters that follow the concentration strategy and $17.6 \%$ of exporting firms that adhere to the spreading strategy). It should be noted that the balanced strategy is the second most popular choice among exporters that concentrate on the EU market: $29.9 \%$ of firms follow this strategy. Of the rest, $54.3 \%$ opt for a concentration strategy, and $15.8 \%$ follow a spreading strategy. 
To further explore alternative diversification strategies, a one-way ANOVA was used to test whether the individual firms follow the concentration, balanced, or spreading strategy. Firm age and time to internationalization were found to have insignificant mean values across the three groups $(F=1.24$ and 1.73 , respectively; both $p$ values were greater than 0.05). The other three descriptive variables - export volume in 2006, ratio of export markets in 2006 to 2003 and ratio of the percentage share of the key market in 2006 to 2003 - were found to have mean values that varied significantly (all had $p$ values of less than 0.001) for the three categories (concentration, balanced, or spreading) of the independent variable.

The data presented in Table 2 confirms the intermediate characteristic of a balanced strategy, as the levels of the clustering variables and the additional descriptive characteristics are positioned between the corresponding levels of the concentration and spreading groups. However, there is an important difference in Germany as a key market characteristic - the share of EU-concentrated exporters with Germany as the key market is slightly higher (33.5\%) in the balanced group than in the spreading group (32.5\%) and much lower than in the concentration group $(63.6 \%$, Table 2$)$. This finding indicates that the adoption of the balanced strategy by the EU-focused exporters is typically linked with the choice of a country, other than Germany, as the key market for their international operations.

We conclude that a strategy of spreading widely across a large number of international markets can be a tempting strategy. However, our findings indicate that seeking revenues from a limited number of key markets is more effective. Therefore,

Proposition 6 In the case of SMEs, the "balanced ambidexterity" strategy is a viable option for both the concentration and the spreading strategies, particularly for expansion outside the EU.

\section{Limitations, implications, and future research}

Geographic diversification of export sales is still an underresearched field. In view of the generally weak empirical base for researching internationalization of SMEs in general and export diversification in particular, we have introduced an alternative method of analysis based on a large microdataset that represents an entire population of exporters. This provides an opportunity for triangulation of the results obtained by other researchers, derived mainly from interviews and questionnaire surveys

In addition, certain patterns identified on the basis of analyzing large datasets can prompt the development of new concepts within the mainstream of internationalization research with important managerial implications. For example, the results of this exploratory research study suggest that for smaller firms concentrating on a single country market with simultaneous penetration of other markets can be an attractive strategy option leading to higher export performance, as compared with more dispersed export sales (Brouthers et al. 2009). However, a single market concentration 
may hamper the growth of export sales. While the wider diversification can be risky due to the limited financial and human resources of SMEs, the balanced concentration strategy, focusing on a limited number of key markets, represents a viable alternative to concentration and spreading export strategies.

Our study shows the importance for SMEs of exports for a home region, especially if the region is an integrated grouping, such as the EU. In Poland, 75\% of SMEs concentrate their international sales efforts on the European Community Single Market. This opens an interesting dilemma for policy makers promoting international activities of smaller firms. It might be argued that with the plethora of available information, elimination of trade barriers, and synchronization of rules between countries to allow for the free movement of people, services, and capital, SME sales within a region should be considered as domestic trade and not exports or imports. Within the European Union Single Market, certain SME export incentives apply exclusively to international operations beyond the EU. The corresponding recommendation for researchers is to focus on SME sales outside the home region, but to consider their involvement in intra-home regional trade as an important explanatory variable.

A clear limitation of our study is due to the fact that the analysis is based on a single country. Comparative research involving a broader spectrum of countries is necessary to validate our findings and separate the impact of country-specific confounding factors. Extending the scope of the research to include exporters from various countries will be essential in determining the impact of the market size of the country of origin and destination countries. It is expected that there will be differences between the international diversification patterns of exporters from larger and smaller countries. Similarities may be found among exporters from countries of different sizes and levels of economic development, according to how the firms are affected by a large export destination, such as the USA in the Western Hemisphere and Germany in Europe.

While the database used in this study encompasses the population of Polish manufacturing exporters numbering 12,409 firms in all, our study is limited by the narrow set of data available for each of the companies. The data lack basic economic and financial information, such as total revenue, profits, and employment. Therefore, we did not investigate a possible bidirectional causality between export performance and the geographical diversification of exports. This type of research requires panel data much richer in detail than what was available. Future studies should explore the direction of causality and whether and how it is affected by the managerial skills and resources of the firm. Studies should control for unobserved firm heterogeneity caused by various factors that may be correlated with, for example, firm size or others characteristics (e.g., Wagner 2003; Bobillo et al. 2010).

Another important limitation is that the analysis is confined to a relatively short period of 4 years (2003-2006). Future studies should be extended longitudinally to obtain a better understanding of export growth patterns and about the effects of business cycle fluctuations on exporting. Even with these limitations, the present cluster analysis did identify patterns of geographic diversification of export sales, which could be further tested with a longer time span through logistic regression analysis and other means. This would further extend our understanding of the phenomena and help us to create appropriate theory and hence develop practices to improve the success of export companies. 
Acknowledgments The authors would like to thank the reviewers for their helpful comments in improving the paper.

Open Access This article is distributed under the terms of the Creative Commons Attribution License which permits any use, distribution, and reproduction in any medium, provided the original author(s) and the source are credited.

\section{References}

Aaby NE, Slater SF (1989) Management influences on export performance: a review of the empirical literature 1978-88. Int Market Rev 6(4):7-26

Acedo F, Jones M (2007) Speed of internationalization and entrepreneurial cognition: insights and a comparison between international new ventures, exporters and domestic firms. J World Bus 42 (3):236-252

Aspelund A, Moen O (2005) Small international firms: typology, performance and implications. Manage Int Rev 45(3):37-57

Aspelund A, Madsen TK, Moen O (2007) A review of the foundation, international marketing strategies, and performance of international new ventures. Eur J Marketing 41(11/12):1423-1448

Autio E (2005) Creative tension: the significance of Ben Oviatt's and Patricia McDougall's article 'Toward a theory of international new ventures'. J Int Bus Stud 36(1):9-19

Autio E, Sapienza HJ, Almeida JG (2000) Effects of age at entry, knowledge intensity, and imitability on international growth. Acad Manage J 43(5):909-924

Barkema HG, Drogendijk R (2007) Internationalization in small, incremental or larger steps? J Int Bus Stud 38(7):1132-1148

Beleska-Spasova E, Glaister KW (2010) Geographic orientation and performance-evidence from British exporters. Manage Int Rev 5(5):533-557

Bell J, McNaughton R, Young S, Crick D (2003) Towards an integrative model of small firm internationalisation. J Int Entrep 1(4):339-362

Bilkey W, Tesar G (1977) The export behaviour of smaller-sized Wisconsin manufacturing firms. J Int Bus Stud 8(1):93-98

Bobillo AM, López-Iturriaga F, Tejerina-Gaite F (2010) Firm performance and international diversification: the internal and external competitive advantages. Int Bus Rev 19(6):607-618

Brouthers L, Nakos G, Hadjimarcou J, Brouthers K (2009) Key factors for successful export performance for small firms. J Int Marketing 17(3):21-38

Cabrol M, Nlemvo F (2009) The internationalisation of French new ventures: the case of the Rhone-Alps region. Eur Manag J 27(4):255-267

Calof JL (1993) The impact of size on internationalization. J Small Bus Manage 31(4):60-69

Cellard S, Prange C (2008) How do age and speed of internationalization affect foreign growth. Academy of Management Conference, Anaheim

Chang J (2007) International expansion path, speed, product diversification and performance among emerging-market MNEs: evidence from Asia-Pacific multinational companies. Asian Bus Manag 6 (4):331-353

Chiu T, Fang DP, Chen J, Wang Y, Jeris A (2001) A robust and scalable clustering algorithm for mixed type attributes in large database environment. Proceedings of the 7th ACM SIGKDD International Conference on Knowledge Discovery and Data Mining, 263-268.

Cieślik J, Kaciak R, Welsh DHB (2010) The strategic effect of early internationalization on survival, consistency, and growth of export sales in small/medium sized enterprises. J Small Bus Strat 21(4):39-64

Contractor F (2007) Is international business good for companies? The evolutionary or multistage theory of internationalization vs. the transaction cost perspective. Focused issue on internationalization and firm performance. Manage Int Rev 47(3):453-475

Crick D (2009) The internationalisation of born global and international new venture SMEs. Int Market Rev 26(4/5):453-476

Crick D, Jones MV (2000) Small high-technology firms and international high-technology markets. J Int Marketing 8(2):63-85

Crick D, Chaudhry S, Batstone S (2000) Revisiting the concentration versus spreading debate as a successful export growth strategy: the case of UK SMEs exporting agricultural-related products. Entrep Region Dev 12(1):49-67 
Dadzie K (1998) Management education for physical distribution and logistics. Int J Phys Distrib Logist Manag 28(4):259-271

Eusebio R, Andreu JL, Belbeze MPL (2007) Internal key factors in export performance. A comparative analysis in the Italian and Spanish textile-clothing sector. J Fash Mark Manag 11(1):9-23

Francis J, Collins-Dodd C (2004) Impact of export promotion programs on firm competencies, strategies and performance: the case of Canadian high-technology SMEs. Int Market Rev 21 (4/5):474-495

Hill E, Brennan J (2000) A methodology for identifying the drivers of industrial clusters: the foundation of regional competitive advantage. Econ Dev Q 14(1):65-96

Hitt MA, Hoskisson RE, Ireland RD (1994) A mid-range theory of the interactive effects of international and product diversification on innovation and performance. J Manage 20(2):297-326

Hitt MA, Hoskisson RE, Kim H (1997) International diversification: effects on innovation and firm performance in product-diversified firms. Acad Manage J 40(4):767-798

Johanson J, Vahlne JE (1977) The internationalization process of the firm - a model of knowledge development and increasing foreign market commitments. J Int Bus Stud 8(1):23-32

Jones MV, Coviello NE (2005) Internationalisation: conceptualising an entrepreneurial process of behaviour in time. J Int Bus Stud 36(3):284-303

Katsikea ES, Leonidou L, Morgan N (2000) Firm-level export performance assessment: review, evaluation, and development. J Acad Market Sci 28(4):493-511

Katsikea ES, Theodosiou M, Morgan RE, Papavassiliou N (2005) Export market expansion strategies of direct-selling small and medium-sized firms: implications for export sales management activities. J Int Marketing 13(2):57-92

Khavul S, Pérez-Nordtvedt L, Wood E (2010) Organizational entrainment and international new ventures from emerging markets. J Bus Venturing 25(1):104-119

Kudina A, Yip GS, Barkema HG (2008) Born global. Bus Strateg Rev 19(4):38-44

Kuha J (2004) AIC and BIC: comparison of assumptions and performance. Sociol Method Res 33(2):188229

Kuivalainen O, Sundqvist S, Servais P (2007) Firms' degree of born-globalness, international entrepreneurial orientation and export performance. J World Bus 42(3):253-267

Lages LF, Lages C, Lages CR (2006) Main consequences of prior export performance results: an exploratory study of European exporters. J Euromarketing 15(4):57-75

Larimo J (2006) Different types of exporting SMEs: similarities and differences in export performance. Adv Int Mar 17:17-62

Lee IH (2010) The M curve: the performance of born-regional firms from Korea. Multinational Business Review 18(4):1-22

Leonidou LC, Katsikeas CS, Samiee S (2002) Marketing strategy determinants of export performance: a meta-analysis. J Bus Res 55(1):51-67

Leonidou LC, Katsikeas CS, Palihawadana D, Spyropoulou S (2007) An analytical review of the factors stimulating smaller firms to export. Implications for policy-makers. Int Market Rev 24(6):735-770

Leonidou LC, Katsikeas CS, Coudounaris DN (2010) Five decades of business research into exporting: a bibliographic analysis. J Int Manag 16(1):78-91

Lin W-T, Liu Y, Cheng K-Y (2011) The internationalization and performance of a firm: moderating effect of a firm's behavior. J Int Manag 17(1):83-95

Locke EA (2007) The case for inductive theory building. J Manag 33(6):867-890

Lu JW, Beamish PW (2006) SME internationalization and performance: growth vs. profitability. J Int Entrep 4(1):27-48

Luostarinen R, Gabrielsson M (2004) Finnish perspectives of international entrepreneurship. Handbook of research on international entrepreneurship. Edward Elgar, Northampton, pp 383-403

March J (1991) Exploration and exploitation in organizational learning. Organ Sci 2(1):71-87

Matanda MJ, Freeman S (2009) Effect of perceived environmental uncertainty on exporter-importer interorganisational relationships and export performance improvement. Int Bus Rev 18(1):89-107

McNaughton RB (2003) The number of export markets that a firm serves: process models versus the bornglobal phenomenon. J Int Entrep 1(3):297-311

Morgan-Thomas A, Jones MV (2009) Post-entry internationalization dynamics: differences between SMEs in the development speed of their international sales. Int Small Bus J 27(1):71-97

O'Cass A, Weerawardena J (2009) Examining the role of international entrepreneurship, innovation and international market performance in SME internationalisation. Eur J Marketing 4(11/12):125-134

OECD (2008) Measuring entrepreneurship. A digest of indicators. OECD, Paris

Oviatt BM, McDougall PP (1994) Towards a theory of international new ventures. J Int Bus Stud 25(1):45-64 
Pangarkar N (2008) Internationalization and performance of small- and medium-sized enterprises. J World Bus 43(4):475-485

Piercy NF (1981) Export strategy: concentration on key markets vs market spreading. J Int Market 1(1):5667

Piercy NF (1982) Export strategy: markets and competition. George Allen and Irwin, London

Preece SB, Miles G, Baetz MC (1999) Explaining the international intensity and global diversity of earlystage technology-based firms. J Bus Venturing 14(3):259-281

Raymond L, Croteau A-M (2006) Enabling the strategic development of SMEs through advanced manufacturing systems: a configurational perspective. Ind Manage Data Syst 106(7):1012-1032

Rugman AM, Verbeke A (2004) A perspective on regional and global strategies of multinational enterprises. J Int Bus Stud 35(1):3-18

Ruzzier M, Hisrich RD, Antoncic B (2006) SME internationalization research: past, present, and future. J Small Bus Enterprise Dev 13(4):476-497

Salomon RM, Shaver JM (2005) Learning by exporting: new insights from examining firm innovation. J Econ Manage Strat 14(2):431-460

Shepherd B (2010) Geographical diversification of developing country exports. World Dev 38(9):12171228

Singh D, Gaur A, Schmid F (2010) Corporate diversification, TMT experience, and performance: evidence from German SMEs. Manage Int Rev 50(1):35-56

Sousa MP, Martínez-López FJ, Coelho F (2008) The determinants of export performance: a review of the research in the literature between 1998 and 2005. Int J Manag Rev 10(4):343-374

Spens K, Kovács G (2006) A content analysis of research approaches in logistics research. Int J Phys Distrib Logist Manag 36(5):374-390

Thomas DE, Eden L (2004) What is the shape of multinationality performance relationship? Multinational Business Review 12(1):89-110

Vachani S (1991) Distinguishing between related and unrelated international geographic diversification: a comprehensive measure for global diversification. J Int Bus Stud 22(2):307-322

Verardi V, Wagner J (2010, May) Productivity premia for German manufacturing firms exporting to the Euro-area and beyond: first evidence from robust fixed effects estimations. IZA Discussion Paper No. 4964

Wagner J (2003) Unobserved firm heterogeneity and the size-exports nexus: evidence from German panel data. Rev World Econ 139(1):161-172

Wheeler C, Beh K, Dimitratos P (2008) UK export performance research: review and implications. Int Small Bus J 26(2):207-239

Zahra SA, Ireland RD, Hitt MA (2000) International expansion by new venture firms: international diversity, mode of market entry, technological learning, and performance. Acad Manage J 43 (5):925-950

Zhang T, Ramakrishnon R, Livny M (1997) BIRCH: a new data clustering algorithm and its applications. Data Min Knowl Disc 1(2):141-182

Zhou H, de Wit G (2009) Determinants and dimensions of firm growth. EIM, Zoetermeer

Zou S, Stan S (1998) The determinants of export performance: a review of the empirical literature between 1987 and 1997. Int Market Rev 15(5):333-356

Zucchella A, Palamara G, Denicolai S (2007) The drivers of the early internationalization of the firm. J World Bus 42(3):268-280 